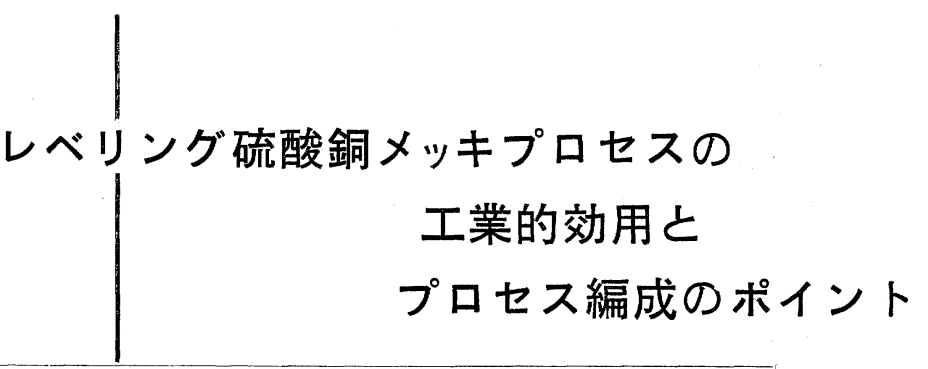

前稿で本プロセスの拈もな工業的効用について述べたが，意外 にも本プロセスの普及和といようである.

その理由について考朰てるときに，むずレベリング硫酸銅メ ッキ自身の生産技術というよりは，前处理に関連した個々の処理 法，そしてプロセスの編成法や日常の作業管理法など，総合的な 問題の解決を急ぐ必要があるように思われる.

そこで今回は鉄鋼素地拉よび亜鉛ダイカスト素地に対する本プ ロセス導入の手がかりを作る意味で，プロセス編成に関するポイ ントを簡単に述べて欢たいと思う。

\section{1. 溶剤洗浄}

\section{（亜鉛ダイカスト素材に対する洗浄法）}

最近, 鉄鋼素材汇対する溶剂洗浄は,コスト 低減や作業環境改善の点で省略される傾向に あり，アルカリ浸セキ洗浄工程がこれに代わ ってきている. したがって本項では亜鉛ダイ カスト素材に対する洗浄法について述べる.

亜鉛ダイカスト素材のミクロ的細孔内に固 着した油脂研摩材が, 前処理工程中 (とくに 予備脱脂工程で）に完全に洗浄されない状態 で，硫酸銅メッキを施すようなことがある と, 表面欠樎部の細孔内部が浸食されて，ピ ット状のメッキ欠宿を誘発することになる。

したがってバフ研摩を施した亜鉛ダイカス ト素材沉いては，溶剤洗浄を省略すること はむずかしい。

一方ではアルカリ浸セキによる予備洗浄法 も検討されているが，まだ工業的問題がな いわけではない、乙かし振動研摩法を適用し たものに対しては, 溶剂洗浄する必要はな
W.
内田大

*前報(上)：実務表面 技術'73-1月号
ではつぎに溶剂洗浄作業の注意事項を考兄 てみる.

(1) バフ研摩面の油脂研摩材は, 研摩後の 放置時間が長くなればなるほど，素地に強 く固着するので, 研摩後はすみやかに予備 洗浄する.

(2) 素地面の細孔内に固着した油脂研摩材

は，溶剤への浸セキ洗浄だけでは不十分で あって，超音波照射洗浄の併用をすすめ る.

(3) 研摩面とくに表面欠陥の細孔内汇固着 した油脂研摩材を洗浄するにあたっては, 溶剂の熱液, 冷液, 蒸気の洗浄順序が効果 的であるが，研摩面の污染状況により適宜 検討する必要がある。

\section{.2 電解研摩（鉄鋼素材では省略する）}

亜鉛ダイカスト素材に対して, 電解研摩が すすめられているのは，素材表面下にあるブ ローホールを露出させたり，素材表面の深い 
細孔, コールドシャット，コールドラップ

(写真 1 参照) の開口部を丸めて, 後の硫酸 銅メッキを細孔内へ深く充テンさせてやるた めである. (写真 2 参照)

このほかに, 表材表面のミクロ的な突起物 を溶かして，表面欠陷部分を平らにする.

一般に亜鉛ダイカスト素材に対する電解研 摩は, 陽極電流密度 $20 \mathrm{~A} / \mathrm{dm}^{2}$ で， 2〜 $4 \mathrm{~min}$ 電解してやれば， 1 〜 $3 \mu$ の表面層が溶解さ れる.したがって適正な作業管理を施せば, バフ研摩や機械的研摩作業よりも経済的と考 えられる. しかし深くて大きい表面欠陷に対 しては, やはりベルトサンダーやエメリー研 摩が有利である。

ではつぎに，ダイヤモンド・アルカリ社の 技術資料に紹介されている作業条件の一部を 述べてみる。

電解液濃度 : “Delozin”アルカリ塩 $674 \mathrm{~g} / l$

浴温度 : $26 \sim 32^{\circ} \mathrm{C}$

陽極電流密度 : $22 \sim 27 \mathrm{~A} / \mathrm{dm}^{2}$

電解電圧 : 10 18V

陰極材：酸化された鋼板

電解除去速度 : $5.1 \sim 7.6 \mu / \mathrm{min}$

\section{3. アルカリ浸セキ洗浄}

最近，鉄鋼素材に対するアルカリ浸セキ洗 浄法の普及は目ざましく，ほとんどの工場が 溶剂洗浄法より転換したか，転換を計画中で

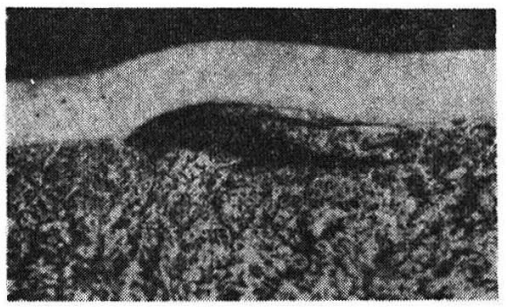

写真 1 従来法により亜鉛ダイカスト素材面 に Cu-Ni-Cr×ッキされた表面欠 陥 (コールドラップ) 部分 2
ある・

一方鉄鋼素材では相当に強いアルカリ洗浄 作業を行なっても，素地面が浸食されたり， 変質するということはほとんどない.

ところが亜鉛ダイカスト素材は，アルカリ 洗浄液に活性であって, 作業管理を誤ると素 地研摩面を荒らしたり,メッキの密着性を悪 くする.

したがって本プロセスの導入後にその効果 をフルに発揮させるためには，一応レペリン グ硫酸銅メッキのすぐれた平滑性を予定した 上で，バフ研摩を油性研摩材を用いない振動 研摩法や回転バレル研摩法に代觉るのが有利 である.

また油性研摩材の付着したバフ研摩面をア ルカリ漫セキ洗浄する場合です, 従来のシア ソ化銅メッキプロセスの時ほど，メッキ面の 肌アレに神径質になる必要はない.

ではつぎに亜鉛ダイカスト素材に対するア ルカリ浸セキ洗浄作業に関する注意事項を考 光てみる.

(1) 素材の表面欠陷細孔内に固着して油脂 研摩剂を十分に洗浄するためには，スプレ 一洗浄法または超音波照射洗浄法を併用す る.

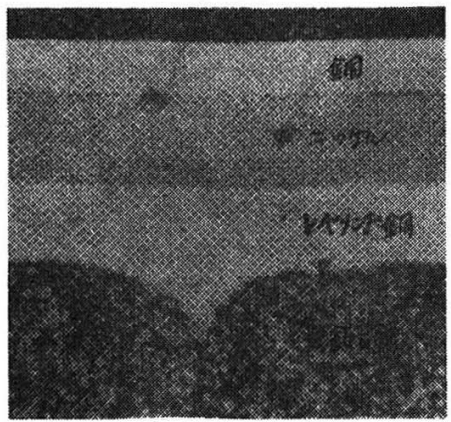

写真 2 亜鉛ダイカスト素材表面欠陥（ピン ホール）面に電解研摩を施し，レべ リング硫酸銅メッキによりカパーさ れた平滑なメッキ面り 
(2) 素材表面欠陥の細孔内に固着した油脂 研摩材を十分に洗浄するために，適当な界 面活性剂を補助剂として添加する。

(3) 洗浄浴中のアルカリ塩は，コロイド状 で洗浄面に付着しやすいので, 洗浄液の管 理については，新しい洗浄剤を補充するだ けでなく，老化液の一部更新を図る.

(4) 洗浄作業にあたっては，固着した油脂 研摩材 (とくに研摩カス) の洗浄効果を高 めるための作業研究とともに, 次工程の水 洗効果をあげる洗浄剤を検討する。

\section{4. 水洗（後工程の水洗作業之共通）}

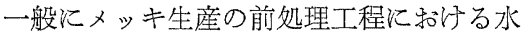
洗作業の大切なことは，十分理解されている と思うが，とくに本プロセスの導入に成功す るためには，各工程間の水洗作業の改善を図 るのが效果的である.

ではつぎに工程間扎打る水洗作業につい て考光てみる.

(1) 表面欠陌部の細孔内に前工程の処理液 が残っていると, 次工程の処理液との反応 生成物を付着しやすいので，アルカリ処理 浴に浸七キ処理後の水洗工程には, 加温水 洗や加圧スプレー水洗などを用いる.

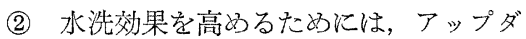
ウン式の多段式水洗槽を用いるとか, 水洗 槽に空気カクハンや機械的カクハンを併用 する.

(3) 水質が悪い場合には，洗浄面をかえっ て污染することがあるので，水洗水のカタ サや腐食性物質については十分な管理を行 なう。

\section{5. 電解 洗 浄}

鉄鋼素材の場合は一般に用いられている陰 極洗浄，陽極洗浄，または P R 電解洗浄法を 適用すれば十分である。

しかし两鉛ダイカスト素材では，素材合金
が化学的に活性であるために電解条件や浴組 成については，細心の注意が必要である。

従来わが国では亜鉛合金に対する電解洗浄 法として，添とんど陰極法が採用されていた ようであるが，本プロセスを導入するために は，陽極洗浄法が有利である.

しかし陽極洗浄法の採用にさいしては，洗 浄面が多少浸食されたり，比較的に厚い酸化 皮膜を作るなどの問題があることも知って拉 かねばならない。

ではつぎに，一般にす寸められている陽極 洗浄法について，注意事項を考兄てみる。

(1) 洗浄面の局部的な洗浄電流密度のバラ ツキが大きいと，洗浄効果のバラッキが大 きいばかりでなく，洗浄面の酸化皮膜形成 にもバラッキを生じやすいので，電流分布 管理が必要である.

(2) 陽極電解洗浄の代表的な浴組成は, 水酸化ナトリウム $4 \mathrm{~g} / l$, 炭酸ナトリ ウ $18 \mathrm{~g} / l$, リン酸三ナトリウム $5 \mathrm{~g} / \mathrm{l}$, メタター酸ナトリウム $30 \mathrm{~g} / l$, 界面活 性剂 $0.5 \mathrm{~g} / \mathrm{l}$, である。

(3) 陽極電解洗浄の代表的な作業条件は, 浴温 $\quad 40 \sim 70^{\circ} \mathrm{C}$, 陽極電流密度 $2 \sim 3$ $\mathrm{A} / \mathrm{dm}^{2}$, 電解時間 $30 \sim 60 \mathrm{~s}$, で岗る.

\section{6. 活性化酸洗净}

\section{6-1 鉄鋼素地の場合}

品物形状が簡単なるのでは，第一層メッキ としては銅昰たはニッケルストライクメッキ を施すこともできるが，パイプ状や板柎接合 部の多い複雑な品物に対しては, 後述する浸 セキニッケルメッキ法などを採用することも ある。

したがって形状の複雑な品物に対する活性 化洗浄作業は，とくに慎重な検討が必要であ る. 
このような場合の活性化洗浄法としては, 一般につぎのものがすすめられている.

(1) 硫酸浴中に打忊了陽極電解活性化洗 浄.

(2) $3 \%$ 塩酸，5\%硫酸浴中での超音波活 性化洗浄.

\section{6-2 亜鉛ダイカスト素地の場合}

亜鉛ダイカスト素地と鉄鋼素地との活性化 作業で基本的に違う点をいえば，まず带鉛ダ イカスト素材は洗浄液に対して浸食されやす いことであり，つぎに活性化洗浄の扣もな目 的が研摩面の活性化というよりも, むしろ表 面欠陥の 細孔内面の活性化にあることであ る.

このような活性化洗浄を有利に行なうに は, 活性化洗浄面のヌレ現象を助けるため に，適量の界面活性剂を添加するなどの工夫 も必要で势る。

\section{7. 第一層メッキ(銅, ニッケルメッキ)}

\section{7-1 鉄鋼素地の場合}

硫酸銅メッキ浴中に鉄鋼素地の露出面を浸 セキすると，銅が鉄鋼素地面は置換析出して くる. この銅置換皮膜は密着が悪く，しかも 粗雑な析出であって，つぎのニッケルメッキ 浴中でハク離して，メッキのザ ラッキになる。

したがって本プロセスでは， 硫酸銅メッキ工程以前に素材全 面に完全な第一層メッキを施し てやるために, つぎのよらなス トライクメッキが不可欠になっ てくる.

（A）シアン化銅ストライクメ ッキ

従来の作業方法を適用すれば よい.

(B) ニッケルストライクメッ キ
ワットのニッケルメッキ浴や高濃度塩化二 ッケルメッキ浴によって，短時間に複覆力の すぐれた薄いニッケルメッキを施してやれば よいが，とくに日常作業管理を獄底しなけれ ばならない.

(C) 浸セキニッケルメッキ1)

本方式は米国ユージライト社で, パイプ内 面や板材接合部分などのとくに低電流密度部 分に対して，第一層ニッケルを析出させるた めに開発されたものである.

このメッキ方式は, 一種のニッケルストラ イクメッキであるが，電解によって一般有効 面にニッケルを析出すると同時に, 電解析出 のさずかしい低電流密度部分には，化学置換 によりニッケルを析出する特長がある.

\section{7-2 亜鉛ダイカスト素材の場合}

亜鉛ダイカスト素材に対する硫酸銅メッキ の問題点といえば，硫酸銅メッキ浴中で亜鉛 合金の化学的反応が速く, ミク口的な細孔内 および深い凹部内の素地が浸食されることで ある・

そしてまた，第一層メッキで被覆されてい ない裸のままの亜鉛合金素材面には，薄い密 着性の悪い化学置換銅を析出して, 後工程で メッキ欠陥の原因となる.

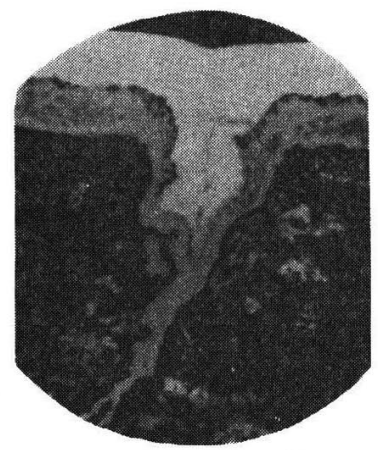

(a) 良

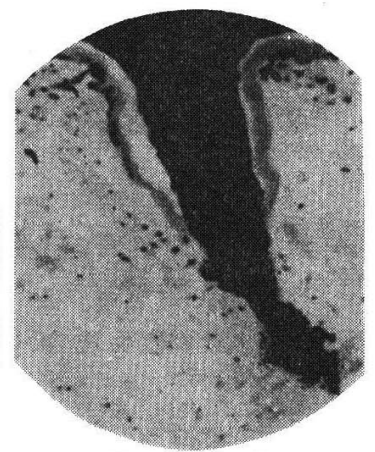

(b) 不
良

写真 3 亜鉛ダイカスト素材表面欠陥細孔内に対する銅スト ライクメッキのミクロスローイングパワー状況図 ${ }^{33}$ 


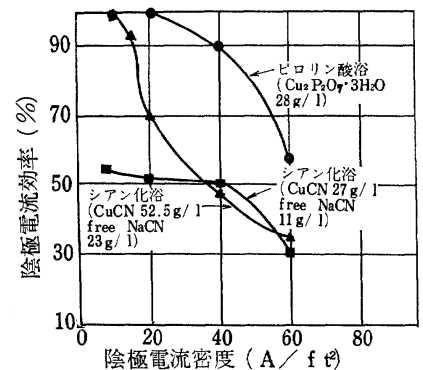

図1 ストライク浴の電流効率電流密度関係 2

これらの点から, 亜鉛ダイカスト素材への 本プロセス適用の成否は，第一層の銅メッキ 技術に大きく左右されてくる.

（写真 3） は表面欠陷の細孔内に対するメ ッキのミクロスローイングパー（微小均一電 着性）の良，不良の状沉図である.

ではつぎに，第一層の銅ストライクメッキ として，シアン化銅ストライクメッキ括よび ピロリン酸銅ストライクメッキについて考光 てみる.

\section{(A) シアン化銅ストライクメッキ22}

従来のシアン化銅ストライクメッキ浴とし ては，低濃度のものが普及していたが，本プ ロセスでは中濃度に近いシアン化銅メッキ浴 が有利でめる。

それは深凹部内の奥深く，また表面欠陷部 のミク口的な細孔内に，十分な第一層銅を析 出させるメッキ性能がすぐれているためであ

\section{る. (図 1, 図 2 参照)}

それでは，(@，(bの代表的なメッキ浴組成 と作業条件を述べてみる。（）内は(bの浴 組成と作業条件である.

シアン化ナトリウム $41.2 \mathrm{~g} / l(78.7 \mathrm{~g} / l)$

シアン化銅 $27.0 \mathrm{~g} / l(52.4 \mathrm{~g} / l)$

遊離シアン化ナトリウム $11.2 \mathrm{~g} / \mathrm{l}$

$\left(20.2 \mathrm{~g} / l^{* 1}\right)$

炭酸ナトリウム $15 \sim 75 \mathrm{~g} / l(3.7 \sim 75 \mathrm{~g} / l)$

浴温 $50 \sim 55^{\circ} \mathrm{C}\left(52 \sim 57^{\circ} \mathrm{C}\right)$

陰極電流密度 $3.2 \sim 6.5 \mathrm{~A} / \mathrm{dm}^{2}$

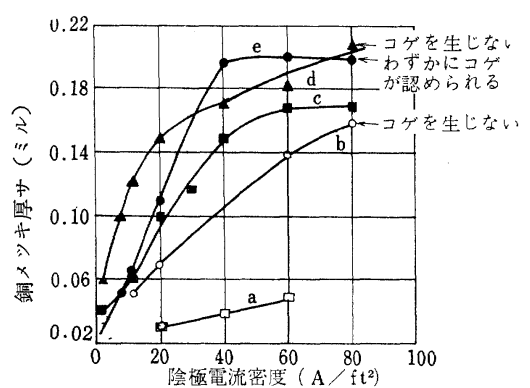

図 2 ストライク浴の浴組成によるメッキ厚 サの変化 ${ }^{2>}$

a: CuCN $18.8 \mathrm{~g} / l$, free $\mathrm{NaCN} 11 \mathrm{~g} / l$
b : CuCN $23 \mathrm{~g} / l$, free NaCN $11 \mathrm{~g} / l$
c: CuCN $27 \mathrm{~g} / l$, free $\mathrm{NaCN} 11 \mathrm{~g} / l$
$\mathrm{~d}: \mathrm{CuCN} 52.5 \mathrm{~g} / l$, free $\mathrm{NaCN} 20 \mathrm{~g} / l$
$\mathrm{e}: \mathrm{Cu}_{2} \mathrm{P}_{2} \mathrm{O}_{7} \cdot 3 \mathrm{H}_{2} \mathrm{O} 28 \mathrm{~g} / l$

$\left(2.2 \sim 3.2 \mathrm{~A} / \mathrm{dm}^{2 * 4}\right)$

メッキ時間 $5 \sim 7 \mathrm{~min}(4 \sim 7 \mathrm{~min})$

※1, シアン化ナトリウムの代わりに， シ アン化アルカリ $26.2 \mathrm{~g} /$ /が用いられる. $※ 2$, (浴の $\mathrm{pH}$ は, 10 11程度.

$※ 3$ ，機械的な浴カクハンを行なう。

※4, 最初の30s は $5.4 \sim 6.5 \mathrm{~A} / \mathrm{dm}^{2}$ でメッ キする.

なおメッキ中に超音波を照射してやること により，陰極効率は30〜60\%向上する.また 細孔内のミクロスローイングパワーを高める ためにも効果的である.

（B）ピロリン酸銅ストライクメッキ3)

現在をだピロリン酸銅ストライクメッキを 採用中の工場はほとんど見受けられないが，

それは工業的プロセスに組及入れた場合， 作業条件の設定や日常作業管理を徹底しない と，密着不良を起こしやすいからである。

らなみに，サフラネック氏はピロリン酸銅 ストライクメッキの特長として，つぎの点を あげて工業化をすすめている。

(1) 正常な作業管理のるとでメッキされた 場合には，シアン化銅ストライクメッキよ りも, 素地との密着性がすぐれている.

(2) 深い山部分やミクロ的な細孔内などの 
低電流密度部に対する被覆力がすぐれてい

\section{る (写真 4 参照)}

（3）超音波照射により限界電流密度が高め られ, 複雑な形状の品物に対して高電流密 度メッキが容易である.

(4) 硫酸銅メッキ以前の酸洗浄が不必要で ある.

ではつぎに，浴組成と作業条件の要点を述 ベてみる.

ピロリン酸カリ $254 \mathrm{~g} / l$

ピロリン酸銅 $28 \mathrm{~g} / l$

クエン酸カリ $23 \mathrm{~g} / l$

浴温 $\quad 22 \sim 30^{\circ} \mathrm{C}$

陰極電流密度 $3.2 \sim 4.3 \mathrm{~A} / \mathrm{dm}^{2}$

超音波照射 $\quad 3.3 \mathrm{w} / l, 20 \sim 100 \mathrm{kc} / \mathrm{s}$

メッキ時間 $\quad 3 \sim 4 \mathrm{~min}(1.2 \sim 4 \mu)$

な招亜鉛ダイカスト素材に対しては，硫酸 銅メッキ以前に銅ストライクメッキを $4 \sim 7$ $\mu$ 施してやるのが無難である.

\section{8. レベリング硫酸銅メッキ}

前述してきたように本プロセス編成上のポ イントは, 硫酸銅メッキ工程に入る以前の工 程にあると考光てよい.

したがって第一層メッキ工程まで順調に進 められていれば，硫酸銅メッキに関する作業 管理は一般の標準作業にしたがって行なえば よい.

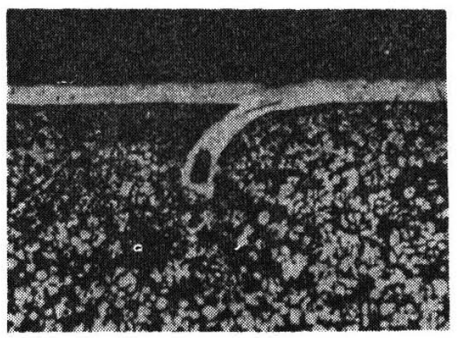

写真4 超音波照射によりピロリン酸銅メッ キ(約 $10 \mu)$ で充テンされた亜鉛ダ イカスト素材面細孔の影微鏡断面写 真4)

\section{9. 光沢ニッケルメッキ}

本プロセス編成にあたっては，レベリング 硫酸銅メッキ以後の編成については, 各工場 の各生産ライン仕様に基ついて，適当にニッ ケルメッキ, クロムメッキ, あるいは真チュ ウメッキ，貴金属メッキ工程などを編成する ことがでさる.

\section{0. おわりに}

本プロセス導入に成功するためには，もち ろん近代的な付属設備や補助添加剤などの開 発も必要であるが，それ以上に，創意工夫に よる作業改善や総合的な生産管理のためのソ フトウェアー開発が大切である.

とくに生産工程の機械化が高度に進んでい る工場では，小回りのきいた日常作業管理や 作業改善がむずかしいために，手動生産工場 よりも導入計画は綿密で, しかもシステマテ ィックに進められなければならない。

現在，本プロセスに関する生産技術では, 目下開発中の問題が多く, 十分な工業データ を紹介できなかったのは残念である。

しかし拙稿がレベリング硫酸銅メッキプロ セス導入の手がかりとなりメッキ生産プロ セス改善に一助できれば望外の喜びである.

\section{文献}

1) C.G.O' Dell, Electroplating and Metal Finishing, 24, 7, 14 (1971)

2) W.H. Safranek, Metal Progress, 91, 5 (1967)

3) ACTISALT $\# 1$, Northwest chemical Co. 資料より

4) W.H. Safranek, H. R. Miller, Plating 55, No. 3 (1968) 